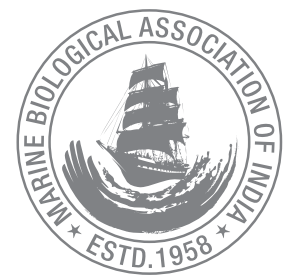

\title{
Occurrence and abundance of plastic particles in razor moonfish along the eastern Arabian Sea
}

\author{
Divya Viswambharan*, Prathibha Rohit, Geetha Sasikumar, Sujitha Thomas, K. K. Joshi', \\ Latha Shenoy ${ }^{2}$ and A. K. Jaiswar ${ }^{2}$ \\ Research Centre of ICAR-Central Marine Fisheries Research Institute, Mangalore-575 001, Karnataka, India. \\ ${ }^{1}$ ICAR-Central Marine Fisheries Research Institute, Kochi- 682 018, Kerala, India. \\ ${ }^{2}$ ICAR-Central Institute of Fisheries Education, Mumbai-400 061, Maharashtra, India. \\ *Correspondence e-mail: divyaarinu@gmail.com
}

Received: 11 April 2019 Accepted: 20 Aug 2019 Published: 30 Aug 2019

Original Article

\begin{abstract}
Rising crisis in marine environment is the presence of plastics in the water column and risk of their input and accumulation in the food web. The present study reports for the first time, the presence of micro and macro plastics in the gut of razor moonfish, Mene maculata. Moonfish plays a major role in the marine food web as prey of large pelagic fishes. The gut analysis of fishes collected from commercial vessels operating along eastern Arabian Sea was analysed to determine the occurrence and abundance of plastic particles with attempt to identify the diet component which might have contributed to the plastic intake in fish. The analysis revealed dominance of plastic particles in gut when dietary component was dominated by eggs. The present study forms baseline information for plastic accumulations in fishes along the eastern Arabian Sea
\end{abstract}

Keywords: Plastic in fish gut, Indian Ocean, plastic fibres

\section{Introduction}

A major threat to oceanic environment is accumulation of marine debris in water column, which is the result of decades of litter entering marine waters (Thompson et al., 2004; Ryan, 2015). Marine debris is a mixture of organic and inorganic matter where plastic particles dominate (GESAMP, 2015). Dominance of plastic in oceans is the direct consequence of its extensive use and high durability (Andrady, 2011) and larger sized plastic particles can affect larger marine organisms by entangling and fatal ingestion (Baltz and Morejohn, 1976; Cawthorn, 1985; Bjomdal and Bolton, 1994; Fossi et al., 2017). The large sized plastic debris is never destroyed but their size gets reduced in due course by the photo degradation and/ or combined effect of wave action. The occurrence of smaller pieces of plastic debris including those not visible to the naked eye, referred to as microplastics (Andrady, 2011) and buoyancy of these particles increases the probability for mixing with surface food sources and increases chances of ingestion by lower trophic level organisms in marine environment (Browne et al., 2008; Naidu et al., 2018). These plastic particles have become so widely spread that neither the oceans in the world nor marine organisms are free from its clutches. Studies have found that 690 species found in marine ecosystem are affected by marine debris of plastic origin (Gall 
and Thompson, 2015) which further includes organisms like whales (Kaladaran et al., 2014), lobsters (Murray and Cowie, 2011), polychaetes (Wright et al., 2013), zooplankton (Cole et al., 2013), lanternfishes (Wieczorek et al., 2018; Lusher et al., 2016; Boerger et al., 2010). The danger of plastic input and accumulation in the food web (Teuten et al., 2009; Galgani et al., 2013) give rise to various issues from internal blockage and disrupted digestion (Jackson et al., 2000) to bio-magnification of harmful chemicals associated with plastic in food chain (Teuten et al., 2009).

There are reports on the occurrence of micro and macro plastics from fish guts from Bay of Bengal (Sivadas et al., 2016) and eastern Arabian Sea (Sulochanan et al., 2014; Kripa et al., 2016; Roul et al., 2018) but to the best of our knowledge, there is complete absence of studies focusing on the abundance of plastic in fish gut from this region. Even though there are many studies conducted round the world on the presence, occurrence, type and abundance of micro plastic in fishes (Moore, 2008; Boerger et al., 2010; Possatto et al., 2011; Davison and Asch, 2011; Ramos et al., 2012; Dantas et al., 2012; Lusher et al., 2013; Neves et al., 2015; Ferreira et al., 2016), only very few studies have tried to make out the diet component which could possibly aid the plastic intake in fishes (Choy and Drazen, 2013; Romeo et al., 2013). To facilitate these objectives, Mene maculata commonly known as moonfish was considered for the current study. The species was selected as it shows both selective and opportunistic feeding (Viswambharan, 2019), with wide distributional range and depth of occurrence along the study area. The fish is mainly distributed at depths ranging from $40 \mathrm{~m}$ to $200 \mathrm{~m}$ in the sub-littoral zone of coastal open waters. The species is free-swimming in schools and shows diel vertical migration. The moonfish is considered a preferred feed of fishes like sailfishes, billfishes and Marlins (Pangalila et al., 2014), emphasise the danger of plastic input and build up in the food web of these large pelagic fishes. Hence an attempt was made to assess the occurrence and abundance of plastic particles in the fish with an effort to identify the diet component which might have contributed to the plastic intake in fish.

\section{Material and methods}

\section{Fish sample collection and preservation}

Samples of moonfish ( $M$. maculata) were collected from multiday trawlers and purse seiners operating along the south eastern Arabian Sea from off Goa to Mangalore (Fig. 1) from December 2015 to August 2017, landed at Mangalore and Malpe Fishing Harbour. The collected samples were preserved in ice and brought to lab. In the laboratory, the fishes were cleaned in running water and preserved in deep freezer $\left(-20^{\circ} \mathrm{C}\right)$.

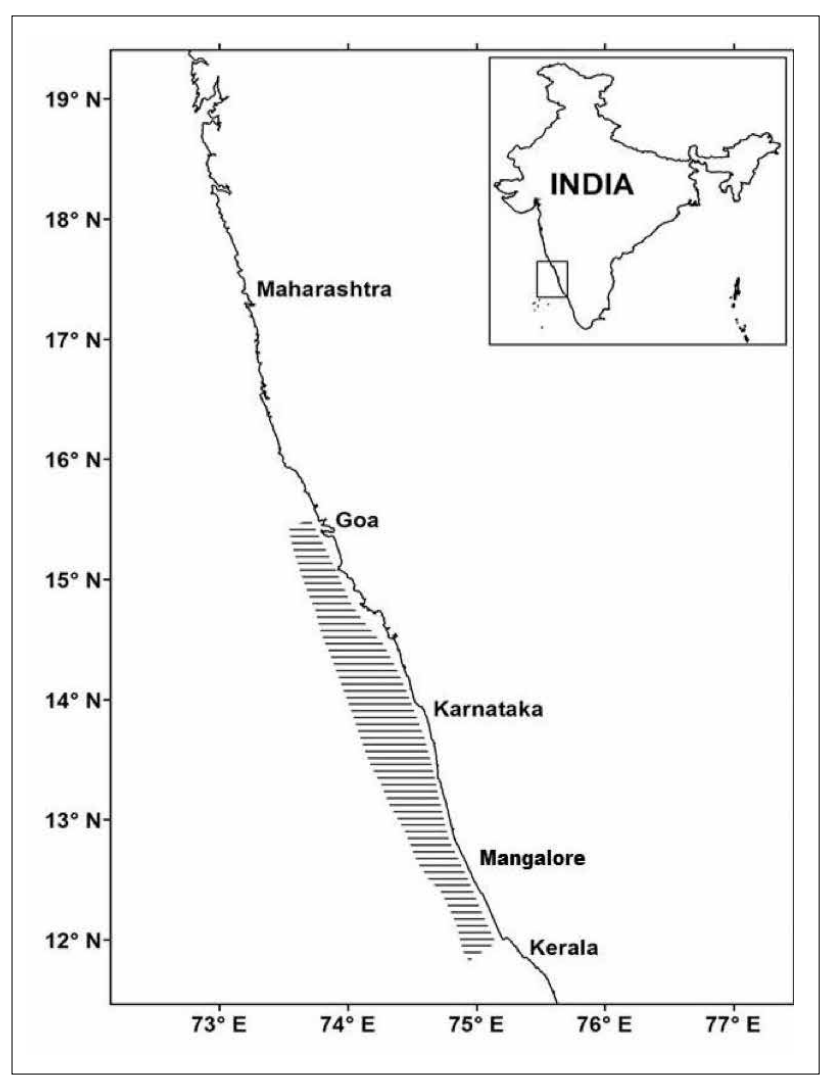

Fig. 1. Map showing the area of operation of mechanised vessels involved in the capture of moonfish along the south eastern Arabian Sea

\section{Feeding ecology and plastic debris contamination}

All the fish samples were processed within 24 hours of sample procurement. The fishes were defrosted prior to analysis and then measurements pertaining to length (TL in $\mathrm{mm}$ ) and weight $(\mathrm{g})$ were recorded. The stomach of each fish was eviscerated and contents were removed. The empty stomach was washed with distilled water to confirm that all items were extracted. The gut contents were analysed using stereomicroscope, and prey items were recognized to lowest possible taxonomic level (Ruppert et al., 2004). The items were washed with distilled water, dried with tissue, weighted and counted. The plastic debris, if observed, along with the gut content while observed under a microscope was separated from food items (Possatto et al., 2011). In order to distinguish the plastic particles from organic matter, the particles were dried. After drying, if the particles weather off, they were considered as organic matter and such samples were discarded (Ferreira et al., 2016). Measurements (both length and thickness) were taken for the non-weathered particles using Nikon Stereo-zoom Phase Contrast Microscope 
(Model Eclipse Ci-S) fitted with Nikon digital sight DS-Fi2 Camera. The form of plastic material, shape and its consistency was also noted.

\section{Data collection, segregation and analysis}

Details on the number of fishes with plastic in gut, number of plastic particles per gut sample, food items observed along with the plastic particle, gut condition and ontogenetic phase while plastic was observed were recorded.

The gut contents were then segregated under five major food types ie, molluscan remains, crustacean remains, fish remains, polychaete remains and eggs. The variations in the gut condition were classified as 'gorged', 'full', three fourth full', "half full', "quarter full', trace and 'empty' based on visual examination. The fishes were considered poorly fed when the stomach conditions were empty or trace, moderately fed when quarter or half full and heavily fed when three forth full, full or gorged. For classification of ontogenetic phase, the fishes with total length (TL) less than $138 \mathrm{~mm}\left(\mathrm{~L}_{\mathrm{m} 50 \%}\right)$ were considered juveniles and those with length equal to or greater than 138 $\mathrm{mm}$ is considered as adult (Viswambharan, 2019)

The number, size and type of plastic particles found in each gut were noted. The plastic particles were classified based on size. Any particle less than $5 \mathrm{~mm}$ was classified as micro plastic and those greater than $5 \mathrm{~mm}$ was classified a macro plastic (Duis and Coors, 2016). The proportion of micro to macro plastics was calculated as number of microplastic particles to macroplastic found in gut.

The quantification of plastic debris ingestion followed three criteria: 1. Frequency of occurrence of plastic (F), 2. Mean plastic particle (Mp) and 3. Plastic abundance (PA).

Where, $\mathrm{F}=$ Number of individuals which had plastic particles in gut / Total number of individuals

$\mathrm{Mp}=$ Total number of plastic items found in fish gut / Total no: of fish which had plastic in gut.

$\mathrm{PA}=$ Mean plastics $(\mathrm{Mp}) \mathrm{X}$ the frequency of occurrence of plastic (F).

Frequency of occurrence of plastic particles in relation to ontogenetic phase, gut condition, season and various diet items were calculated. ' $F$ ' if expressed in percent, is represented as \%F.

\section{Statistical analysis}

XLStat 2017.5 and Past 3.1 software was used to analyse the data. The $F$ in relation to various food types were compared using the chi-squared test for equality of more than 2 proportions ( $K$ proportion test) at $5 \%$ significance. If the null hypothesis of equal proportions was rejected, then the Marascuillo procedure was used to identify the group proportions which differed significantly. The same method was used to analyse the frequency of occurrence of plastic particles with respect to different seasons and gut conditions. $X Y$ plot using PA vs $F$ (in relation to various food types), was plotted to identify the food item with which plastic particles were found in abundance. The ' $F$ ' in relation to ontogenetic phase and proportion of plastic types observed in the fish guts were tested using chi-square test $(p<0.05)$.

\section{Results}

The 810 fishes of Razor moonfish; M. maculata examined were in the length range of 55 to $255 \mathrm{~mm}$. Of the total 810 fishes examined, only 13 fishes had the presence of plastic fibre in the stomach, which accounts to $1.61 \%(\% \mathrm{~F})$ of the total fish examined (Fig. 2). During the analysis, 33 plastic fibres were observed in the gut of 13 fishes with Mp of 2.54 and PA of 0.041 fibres per fish. The size of these fibres ranged from 0.01 to $12 \mathrm{~mm}$ in length and thickness less than $1 \mathrm{~mm}$.

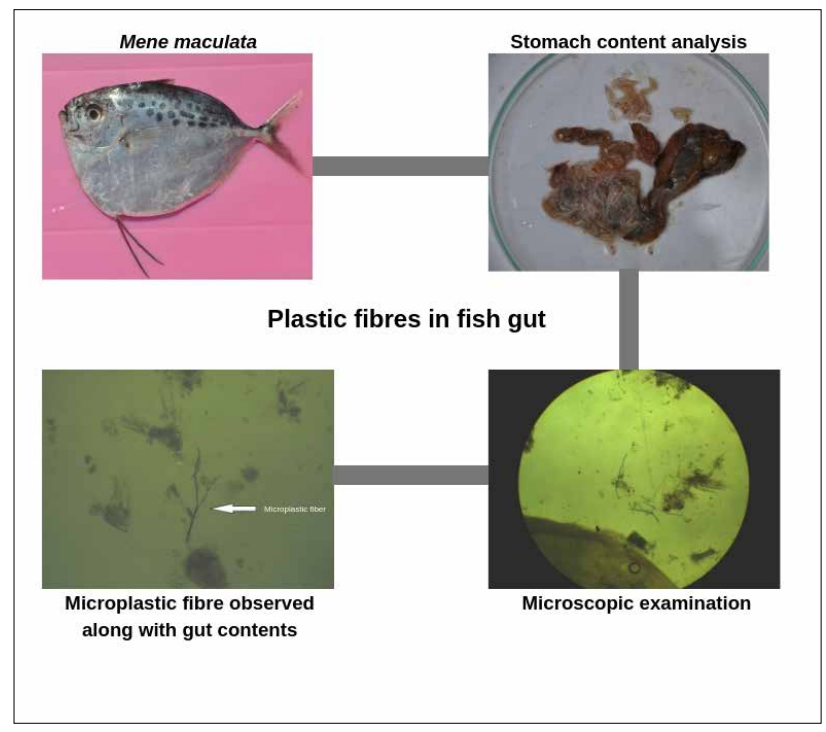

Fig. 2. Illustration of plastic fibre observed in fish gut

\section{$F$ in relation to ontogenetic phase}

Of the 265 juvenile fishes examined, only one fish $(\% \mathrm{~F}=0.38 \%)$ had plastic fibre in gut, while 12 out 545 adults $(\% \mathrm{~F}=2.20 \%)$ had plastic fibre in gut. The Chi-square test revealed that there is no significant difference in the occurrence of plastic between juveniles and adults $(\chi 2=4.9048 ; p>0.05)$. 


\section{Proportion of micro plastic vs macro plastic}

A total of 33 plastic fibres were obtained from 13 guts of moonfish of which 31 were micro plastic and 2 were macro plastic. In the fish with plastic fibre in gut, the presence of micro plastic fibres were significantly higher than the macro plastic fibres $(\chi 2=25.49 ; p<0.01)$.

\section{' $F$ ' in relation to gut condition}

It has been observed that, $1 \%(8 / 729)$ of the poorly fed, $5 \%(2 / 41)$ of moderately fed and $8 \%(3 / 40)$ of the heavily fed fishes had plastic in gut. There is significant difference in the occurrence of plastic particles in relation to different gut condition $(\chi 2=6.5$; $p<0.05)$, but Marascuillo procedure failed to distinguish the three groups due to low sample size.

\section{' $F$ ' in relation to seasonal variation}

The $\% \mathrm{~F}$ of micro plastic recorded a higher value of $2.61 \%$ for the pre-monsoon season in contrast to the $0.66 \%$ and $0.96 \%$ respectively for monsoon and post-monsoon seasons (Table 1). Seasonal variations in the occurrence of plastic fibre in the gut content were not significant $(\chi 2=5.99 ; p>0.05)$.

\begin{tabular}{lllll}
\multicolumn{4}{l}{ Table 1. Season-wise changes observed in the occurrence of plastic in moonfish } \\
\hline Season & $\begin{array}{l}\text { No. of fish } \\
\text { examined }\end{array}$ & $\begin{array}{l}\text { No. of } \\
\text { plastic Fibre }\end{array}$ & $\begin{array}{l}\text { Type of plastic fibre } \\
\text { obtained }\end{array}$ & $\begin{array}{l}\text { No. of fish with } \\
\text { plastic in gut }\end{array}$ \\
\hline Pre-Monsoon & 345 & 25 & Micro Plastic Fibre & 9 \\
\hline Monsoon & 152 & 2 & Macroplastic & 1 \\
\hline Post- Monsoon & 313 & 6 & Micro plastic Fibre & 3 \\
\hline
\end{tabular}

\section{' $F$ ' in relation to fish diet content}

Dietary variation plays a significant role in the occurrence of plastic fibres in the gut of moonfish. The fish diet items like eggs, remains of molluscs, crustaceans, fishes and polychaetes, had plastic fibres with them (Table 2). A negligible number of empty stomachs $(0.15 \%$ of total empty guts) had plastics fibre in gut. The only presence of macro plastic in gut (2nos) was observed in empty stomach. The plastic occurrence $(F)$ recorded a higher value of 0.44 for the fishes which feeds on 'eggs' in contrast to the other dietary items. The XY plot (Fig. 3) using occurrence of plastic (F) vs plastic abundance (PA) showed that the gut which had 'eggs' as major diet has higher abundance of plastic fibres. Results of $K$ proportion test showed a significant variation in the occurrence of micro plastic $\left(\chi^{2}\right.$ value $\left.=194.227 ; p<0.001\right)$ with major food items in gut. The results of the Marascuillo procedure showed that the occurrence of plastic fibre in guts where eggs dominated is significantly different from empty guts (Table 3 ).

Table 2. Summary of total number of fishes examined, number of micro plastic fibre seen in gut and number of fish with plastic in gut.

\begin{tabular}{llll}
\hline Diet items & $\begin{array}{l}\text { No. of fishes } \\
\text { examined }\end{array}$ & $\begin{array}{l}\text { No. of fish with } \\
\text { plastic in gut }\end{array}$ & No. of plastic fibre \\
\hline Empty & 689 & 2 & 3 \\
\hline Molluscan remains & 22 & 1 & 5 \\
\hline Crustacean remains & 49 & 1 & 3 \\
\hline Digested fish remains & 24 & 1 & 2 \\
\hline Egg & 16 & 7 & 19 \\
\hline Polychaetes & 10 & 1 & 1
\end{tabular}

Table 3. The results of Marascuilo procedure conducted for the occurrence of microplastic with major diet items in gut.

\begin{tabular}{|c|c|c|c|}
\hline \multicolumn{4}{|l|}{ Marascuilo procedure } \\
\hline Contrast & Value & Critical value & Significant \\
\hline $\mid p$ (Empty stomach) - $p$ (Molluscan remains) $\mid$ & 0.043 & 0.148 & No \\
\hline $\mid p$ (Empty stomach) - $\mathrm{p}$ (Crustacean remains) $\mid$ & 0.018 & 0.068 & No \\
\hline $\mid p$ (Empty stomach) - $p$ (Fish remains) $\mid$ & 0.039 & 0.136 & No \\
\hline $\mid p($ Empty stomach) - $p(E g g) \mid$ & 0.435 & 0.413 & Yes \\
\hline $\mid p$ (Empty stomach) - $p$ (Polychaetes) $\mid$ & 0.097 & 0.316 & No \\
\hline $\mid p$ (Molluscan remains) - $p$ (Crustacean remains) $\mid$ & 0.025 & 0.162 & No \\
\hline $\mid p$ (Molluscan remains) - $p$ (Fish remains) $\mid$ & 0.004 & 0.201 & No \\
\hline $\mid p$ (Molluscan remains) - $\mathrm{p}($ Egg $) \mid$ & 0.392 & 0.438 & No \\
\hline $\mid p$ (Molluscan remains) - $p$ (Polychaetes) $\mid$ & 0.055 & 0.349 & No \\
\hline $\mid p$ (Crustacean remains) $-p$ (Fish remains) $\mid$ & 0.021 & 0.151 & No \\
\hline $\mid p($ Crustacean remains $)-p(E g g) \mid$ & 0.417 & 0.418 & No \\
\hline $\mid p($ Crustacean remains $)-p$ (Polychaetes $) \mid$ & 0.080 & 0.323 & No \\
\hline $\mid p$ (Fish remains) $-p(E g g) \mid$ & 0.396 & 0.434 & No \\
\hline $\mid p$ (Fish remains) - $p$ (Polychaetes $) \mid$ & 0.058 & 0.344 & No \\
\hline $\mid p($ Egg $)$ - $p($ Polychaetes $) \mid$ & 0.338 & 0.520 & No \\
\hline
\end{tabular}




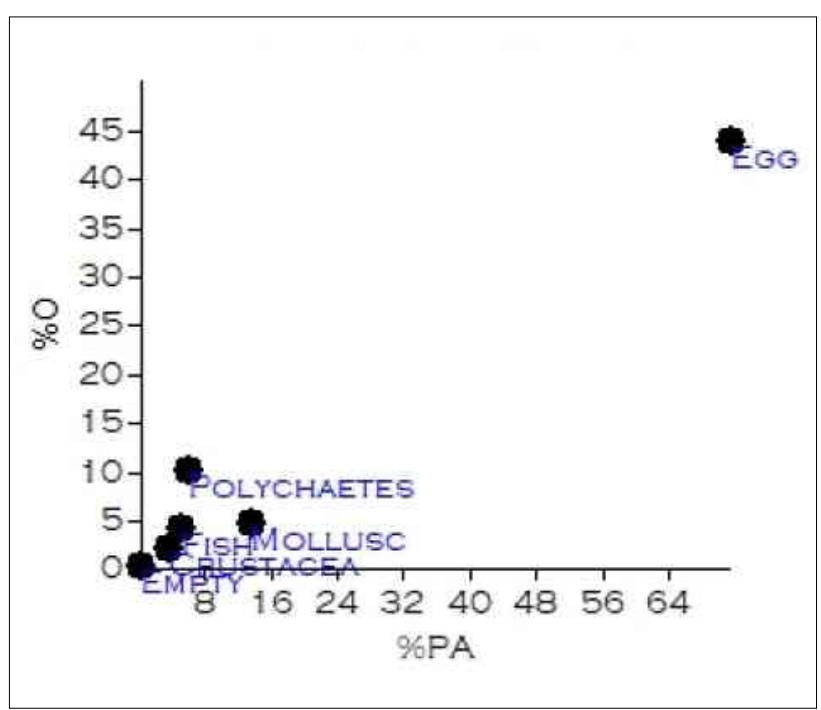

Fig. 3. XY plot showing the percentage of occurrence of plastic against plastic abundance in various diet contents of moonfish

\section{Discussion}

Micro plastics are major pollutants and they were found in large quantities in the coastal and pelagic environment of seas around the world (Wieczorek et al., 2018; Rayn, 2015). This plastic debris is key threat to aquatic organisms, especially in marine environment due to the lethal effects caused by accidental ingestion or absorbing pollutants seen on the surface of plastic particles (Chua et al., 2014; Lavers et al., 2014; Tanaka et al., 2013). Many studies have been conducted to assess the occurrence of micro plastic ingestion by marine fishes and it usually ranges between 0.3 (south eastern Australia) to $73.39 \%$ (northern Atlantic) (Cannon et al., 2016; Wieczorek et al., 2018). In the present study, the occurrence percentage of plastics in moonfish is very low $(1.61 \%)$. The occurrence percentage of plastic particles in near shore marine fishes like sardines $(n=10)$ and mackerels $(n=10)$ seen in same region, i.e., south eastern Arabian Sea, is in the range of $50-60 \%$ (Sulochanan et al., 2014). Even though the study was conducted in same region, diverse fish species in same sea having different feeding modes, dissimilar diet composition and feeding grounds might exhibit differential intake of plastics (Vendel et al., 2017; Kripa et al., 2016; Cannon et al., 2016) leading to wide variation in plastic occurrence in fishes.

The plastic abundance per fish in the present study is (0.041) low when compared to the average value observed in studies which is conducted in marine environment across the world. The abundance of plastic per fish ranged from $1.8 \pm 0.19$ in northwest Atlantic (Wieczorek et al., 2018) to $3.75 \pm 0.25$ in Balearic Island (Nadal et al., 2016). From the previous reports (Eriksen et al., 2014; Tanaka and Takada, 2016; Nadal et al., 2016; Cannon et al., 2016; Ferreira et al., 2016; Wieczorek et al., 2018) it is clear that the occurrence of plastic in fish guts correlates to the microplastic abundance in the habitat water. The average density of microplastic fibres observed in the coastal waters of eastern Arabian Sea is 3-4 nos per cubic metre (CMFRI, 2016). Since the plastic abundance in the surface waters of eastern Arabian Sea is comparatively low, it can be assumed that the study area is less polluted with plastic which lead to the lower plastic abundance in fish gut.

The ontogenetic stage of the fish might also influence the intake of plastic in certain fishes (Cannon et al., 2016; Hoss and Settle, 1990). Current study reveals no significant difference in the occurrence of plastic between juveniles and adults, which could be concluded as microplastic ingestions are independent of ontogenic stages (Possatto et al., 2011; Dantas et al., 2012). It was observed that only fibres were encountered in the gut of fishes and micro fibres dominated significantly. The higher prevalence of fibre in the gut could be due to the dominance of micro fibres in the coastal areas in the Indian Ocean (Abayomi et al., 2017).

In the present study, seasonal variation in the occurrence of plastic in fish gut was observed and higher ' $\mathrm{F}$ ' was seen in pre-monsoon compared to monsoon and post-monsoon season, but the variation was not significant. Though there are reports on seasonal variation in plastic occurrence in fishes (Ferreira et al., 2016), the current study fails to bring out significant variation.

In eastern Arabia Sea the effect of land discharge is considered the major reason for occurrence of micro plastic in coastal waters which ultimately lead to the ingestion of these by filter feeding fishes like sardines and mackerels (Sulochanan et al., 2013; Kripa et al., 2016). Moonfish shows both selective feeding (organism actively preying on desired food items) and opportunistic feeding in the absence of desired food items. So, it can be postulated that the occurrence of microplastic in gut might be linked with fish feeding habit (Choy and Drazen, 2013) and the diet of the fish (Romeo et al., 2013). It was observed that the plastic abundance was significantly more when diet of the fish was eggs. The studies on the feeding ecology of fishes showed that moonfish is carnivorous in nature where juvenile feeds mainly on the small zooplankton crustaceans while the adults shifted to cephalopods, larger zooplankton crustaceans and teleosts (Viswambharan, 2019). The eggs which were observed in the gut of moonfish were ingested as a part of opportunistic feeding shown by fish. The pelagic eggs have the comparable density of micro-plastic (Lima et al., 2014) and these micro plastics fibres which were floating or attached with eggs should have been consumed by fishes, leading to the higher prevalence of plastic fibres in fish gut along with the pelagic eggs. Cannon et al. (2016) obtained 
microplastic from the gut of Antarctic toothfish, which had fish eggs and parasitic nematodes.

In the present study, it was noticed that $0.29 \%$ of the empty guts and $9.1 \%$ of the gut with food had plastic. This clearly indicates that the retention of microplastic fibres in gut is very less. The studies on the retention of micro plastic in fishes like goldfish, White Sucker and Fathead Minnow indicates that micro plastics are not likely to accumulate within the gut contents of fish over successive meals (Grigorakis et al., 2017). It is seen that the microplastic dominated the guts whereas macroplastic were very feebly observed. This could be because, these microplastics could favour ingestion by organisms in conjunction with their small dimensions (Taylor et al., 2016).

The incidence of plastic particles in fish gut is a global phenomenon which has to be viewed upon with its far reaching consequence. Though the occurrence and abundance of plastic particles in moonfish seen along the eastern Arabian Sea is not in an alarming state, studies are essential to comprehend the impacts of plastic debris on the life cycle of fish. Higher incidence of plastic fibres were observed when fish diet was pelagic eggs which accentuate the importance of diet preferences in plastic ingestions. The present study forms baseline information for plastic accumulations in fishes along the eastern Arabian Sea and more studies are required on varied fishes with different feeding habits and dietary preferences to clearly understand the relationship between the diet and plastic intake. Further studies are needed to understand the impacts of plastic debris on the general health of plastic ingested fish and to examine the possibility of pollutant transfer to higher trophic levels, and to investigate probable actions to protect marine organisms from micro and macro plastic pollutions.

\section{Acknowledgements}

The authors are grateful to Director, ICAR-CMFRI for the constant encouragement.

\section{References}

Abayomi, O. A., P. Range, M. A. Al-Ghouti, J. P. Obbard, S. H. Almeer and R. BenHamadou. 2017. Microplastics in coastal environments of the Arabian Gulf. Mar. Pollut. Bull., 124: 181-188.

Andrady, A. L. 2011. Microplastics in the marine environment. Mar. Pollut. Bull., 62(1): 596-605.

Baltz, D. M. and G. V. Morejohn. 1976. Evidence from seabirds and plastic particle pollution off central California. Western Birds, 7: 111-112.

Bjomdal, K. A. and A. B. Bolton. 1994. Effects of marine debris on sea turtles. In Poster Abstracts and Manuscripts from the Third International Conference on Marine Debris, 1994, ed. C. Clary. U.S. Department of Commerce. NOAATMNMFS-AFS- 51.

Boerger, C. M., G. L. Lattin, S. L. Moore and C. J. Moore. 2010. Plastic ingestion by planktivorous fishes in the North Pacific central gyre. Mar. Pollut. Bull., 60: 2275-2278.

Browne, M. A., A. Dissanayake, T. S. Galloway, D. M. Lowe and R. C. Thompson. 2008. Ingested microscopic plastic translocates to the circulatory system of the mussel,
Mytilus edulis (L.). Environ. Sci. Tech., 42: 5026-5031.

Cannon, S. M. E., Jennifer L. Lavers and F. Bianca. 2016. Plastic ingestion by fish in the Southern Hemisphere: A baseline study and review of methods. Mar. Pollut. Bull., 107(1): 286-291.

Cawthorn, M. W. 1985. Entanglement in, and ingestion of, plastic litter by marine mammals, snakes, and turtles in New Zealand waters. In Proceedings of the Workshop on the Fate and Impact of Marine Debris, 1984, ed. R. S. Shomura and H. O. Yoshida. U.S. Department of Commerce. NOAA-TM-NMFS-SWFSC-54:336343.

Choy, A. C. and J. C. Drazen, 2013. Plastic for dinner? Observations of frequent debris ingestion by pelagic predatory fishes from the central North Pacific. Mar. Ecol. Prog. Ser., 485: 155-163.

Chua, E. M., J. Shimeta, D. Nugegoda, P. D. Morrison and B. O. Clarke. 2014. Assimilation of Polybrominated diphenyl ethers from microplastics by the marine amphipod, Allorchestes compressa. Environ. Sci. Tech., 48: 8127-8134.

CMFRI. 2016. Annual Report 2015-16. Central Marine Fisheries Research Institute, Kochi. 294 pp.

Cole, M., P. Lindeque, E. Fileman, C. Halsband, R. Goodhead and J. Moger. 2013. Microplastic ingestion by zooplankton. Environ. Sci. Technol., 47(12): 6646-55.

Dantas, D. V., M. Barletta and M. F. Da Costa. 2012. The seasonal and spatial patterns of ingestion of polyfilament nylon fragments by estuarine drums (Sciaenidae). Environ. Sci. Pollut. Res., 19: 600-606.

Davison, P. and R. G. Asch. 2011. Plastic ingestion by mesopelagic fishes in the North Pacific Subtropical Gyre. Mar. Ecol. Prog. Ser., 432: 173-180.

Duis, K. and A. Coors. 2016. Microplastics in the aquatic and terrestrial environment: sources (with a specific focus on personal care products), fate and effects. Environ. Sci. Eur., 28:1-25.

Eriksen, M, L., C. M. Lebreton, H. S. Carson, M. Thiel, J. Moore and J. C. Borerro, 2014 Plastic Pollution in the World's Oceans: More than 5 Trillion Plastic Pieces Weighing over 250,000 Tons Afloat at Sea. PLOS ONE, 9(12): 1-15.

Ferreira, G. V., M. Barletta, A. R. Lima, D. V. Dantas, A. K. Justino and M. F. Costa. 2016 Plastic debris contamination in the life cycle of Acoupa weakfish (Cynoscion acoupa) in a tropical estuary. ICES J. Mar. Sci., 73: 2695-2707.

Fossi, M. C., T. Romeo, M. Baini, C. Panti, L. Marsili and T. Campani. 2017. Plastic debris occurrence, convergence areas and fin whales feeding ground in the Mediterranean marine protected area Pelagos sanctuary: a modelling approach. Front. Mar. Sci., 4(167): 1-15.

Galgani, F., G. Hanke, S. Werner and L. De Vrees. 2013. Marine litter within the European Marine Strategy Framework Directive, ICES J. Mar. Sci. 70(6):1055-1064.

Gall S. C. and R. C. Thompson. 2015. The impact of debris on marine life. Mar. Pollut. Bull., 92:170-79.

GESAMP, 2015. Sources, fate and effects of microplastics in the marine environment: a global assessment. Rep. Stud. GESAMP 90: 96

Grigorakis, S., S. Mason and K. G. Drouillard. 2017. Determination of the gut retention of plastic microbeads and microfibers in goldfish (Carassius auratus). Chemosphere, 169: $233-238$

Hoss, D. E. and L. R. Settle. 1990. Ingestion of plastics by teleost fishes. Proceedings of the Second International Conference on Marine Debris. NOAA Technical Memorandum 154: 693-709.

Jackson G. D., N. G. Buxton and M. J. A. George. 2000. Diet of the southern opah Lamprisim maculatus on the Patagonian Shelf; the significance of the squid, Moroteuthis ingens and anthropogenic plastic. Mar. Ecol. Prog. Ser., 206: $261-271$

Kaladharan, P., P. K. Asokan, M. Koya and H. M. Bhint. 2014. Plastic debris in the stomach of a Longman's Beaked Whale, Indopacetus pacificus (Longman, 1926) stranded off Sutrapada, Veraval, Saurashtra coast, India. J. Mar. Biol. Ass. India, 56 (2): 92-94.

Kripa, V., P. Kaladharan, D. Prema, R. Jeyabaskaran, P. S. Anilkumar, G. Shylaja, K. K. Saji Kumar, A. Anasu Koya, P. G. Nair, K. S. Abhilash, A. M. Dhanya, J. Bose, T. V. Ambrose, N. D. Divya, P. G. Vishnu and G. Mohan. 2016. National Marine Debris Management Strategy to conserve marine ecosystems. Mar. Fish. Inform. Serv. Tech. Ext. Ser., 228: 3-10.

Lavers, J. L., A. L. Bond and I. Hutton. 2014. Plastic ingestion by Flesh-footed Shearwaters (Puffinus carneipes): Implications for fledgling body condition and the accumulation of plastic-derived chemicals. Environ. Pollut., 187: 124-129.

Lima, A. R. A., M. F. Costa and M. Barletta. 2014. Distribution patterns of microplastics within the plankton of a tropical estuary. Environ. Res., 132: 146-155.

Lusher, A. L., C. O' Donnel, R. Officer and I. O' Connor. 2016. Microplastic interactions with North Atlantic mesopelagic fish. ICES J. Mar. Sci., 73:1214-1225.

Lusher, A. L., M. McHugh and R. C. Thompson. 2013. Occurrence of microplastics in the gastrointestinal tract of pelagic and demersal fish from the English Channel. Mar. Pollut. Bull., 67: 94-99.

Moore, C. J. 2008. Synthetic polymers in the marine environment: a rapidly increasing, long-term threat. Environ. Res., 108:131-139.

Murray, F. and P. R. Cowie. 2011. Plastic contamination in the decapod crustacean Nephrops norvegicus (Linnaeus, 1758). Mar. Pollut. Bull., 62: 1207-1217. 
Nadal, M. A., C. S. Alomar and S. Deudero. 2016. High levels of microplastic ingestion by the semipelagic fish Bogue Boops boops (L.) around the Balearic Islands. Environ. Pollut., 214:517-523.

Naidu, S. A., R. V. Rao and K. Ramu. 2018. Microplastics in the benthic invertebrates from the coastal waters of Kochi, Southeastern Arabian Sea. Environ. Geochem. Health, 40(4): 1377-1383.

Neves, D., P. Sobral, J. L. Ferreira and T. Pereira. 2015. Ingestion of microplastics by commercial fish off the Portuguese coast. Mar. Pollut. Bull., 101:119-126.

Pangalila, F. P.T., J. Budiman, A. T. R. Telleng and E. Reppie. 2014. Fisheries Studies of Mene maculata in Buyat Bay; Journal IPTEKS PSP, 1(2):103 - 111.

Possatto, P. E., M. Barletta, M. F. Costa, J. A. Ivar do Sul and D. V. Dantas. 2011. Plastic debris ingestion by marine catfish: an unexpected fisheries impact. Mar. Pollut. Bull., 62: 1098-1102.

Ramos, J. A., M. Barletta and M. F. Costa. 2012. Ingestion of nylon threads by Gerreidae while using a tropical estuary as foraging grounds. Aquat. Biol., 17: 29-34.

Romeo, T., C. Pedà, M. C. Fossi, F. Andaloro and P. Battaglia. 2013. First record of plastic debris in the stomach of Mediterranean lantern fishes. Acta. Adriat., 57(1): $115-124$

Roul, S. K., T. B. Retheesh, M. Radhakrishnan, D. Prakasan, A. R. Akhil, K. T. S. Sunil, S. N. A. Augustine, P. K. Seetha and P. U. Zacharia 2018. Plastic debris entangled silky shark landed. Mar. Fish. Inform. Ser. Tech. Ext. Ser., 235: 24-25.

Ruppert, E. E., R. S. Fox and R. D. Barnes. 2004. Invertebrate Zoology, a Functional Evolutionary Approach. 7th ed. Brooks/ Cole-Thomson Learn, Belmon. 963 pp.

Ryan, P. G. 2015. A brief history of marine litter research. Marine Anthropogenic Litter (eds. M. Bergmann, L. Gutow and M. Klages) Dordrecht: Springer, p 1-25.

Sivadas, M., K. K. Suresh and K. Kannan. 2016. Incidents of ingestion of plastic by marine fishes. Mar. Fish. Inform. Serv. Tech. Ext. Ser., 227: 19-20.

Sulochanan, B., G. S. Bhat, S. Lavanya, A. P. Dineshbabu and P. Kaladharan 2014. Preliminary assessment of ecosystem process and marine litter in the beaches of Mangalore. Indian J. Geo-Mar. Sci., 43 (9): 1-6.
Tanaka, K. and H. Takada. 2016. Microplastic fragments and microbeads in digestive tracts of planktivorousfsh from urban coastal waters. Sci. Rep., 6: 34351.

Tanaka, K., H. Takada, R. Yamashita, K. Mizukawa, M. A. Fukuwaka and Y. Watanuki. 2013. Accumulation of plastic-derived chemicals in tissues of seabirds ingesting marine plastics. Mar. Pollut. Bull., 69(1-2): 219-222.

Taylor, M. L., C. Gwinnett, L. F. Robinson and L. C. Woodall. 2016. Plastic microfibre ingestion by deep-sea organisms. Sci. Rep., 6: 33997.

Teuten, E. L., J. M. Saquing, D. R. U. Knappe, M. A. Barlaz, S. Jonsson, A. Björn, S. J. Rowland, R. C. Thompson, T. S. Galloway, R. Yamashita, D. Ochi, Y. Watanuki, C. Moore, P. H. Viet, T. S. Tana, M. Prudente, R. Boonyatumanond, M. P. Zakaria, K. Akkhavong, Y. Ogata, H. Hirai, S. Iwasa, K. Mizukawa, Y. Hagino, A. Imamura, M. Saha and $\mathrm{H}$. Takada. 2009. Transport and release of chemicals from plastics to the environment and to wildlife. Phil. Trans. R. Soc. B, 364(1526): 2027-2045.

Thompson, R. C., Y. Olsen, R. P. Mitchell, A. Davis, S. J. Rowland, A. W. G. John, D. McGonigle and A. E. Russell. 2004. Lost at sea: Where is all the plastic? Science, 304 (5672): 838

Vendel, A. L., F. Bessa, V. E. N. Alves, A. L. A. Amorim, J. Patrício and A. R. T. Palma 2017. Widespread microplastic ingestion by fish assemblages in tropical estuaries subjected to anthropogenic pressures. Mar. Pollut. Bull., 117: 448-455.

Viswambharan, D. 2019. Biology and stock delineation of Razor moonfish, Mene maculata along the Konkan Malabar Coast of India. PhD thesis, Central Institute of Fisheries Education, Mumbai, $121 \mathrm{pp}$.

Wieczorek A. M., Morrison Liam, L. Croot Peter, Allcock A. Louise, MacLoughlin Eoin, Savard Olivier, Brownlow Hannah and K. Doyle Thomas. 2018. Frequency of Microplastics in Mesopelagic Fishes from the Northwest Atlantic. Front. Mar. Sci., 5:39-48.

Wright, S. L., R. C. Thompson and T. S. Galloway. 2013. The physical impacts of microplastics on marine organisms: A zooplankton. Environ. Sci. Tech., 47: 6646-6655. 